\title{
SURPRISE HEIRS
}

\author{
Volume 1 \\ Illegitimacy, Patrimonial Rights, and Legal Nationalism \\ in Luso-Brazilian Inheritance, 1750-1821
}





\title{
SURPRISE HEIRS \\ Volume 1
}

\author{
Illegitimacy, Patrimonial Rights, \\ and Legal Nationalism in \\ Luso-Brazilian Inheritance, 1750-1821
}

LINDA LEWIN

STANFORD UNIVERSITY PRESS

STANFORD, CALIFORNIA

2003 


\section{Stanford University Press \\ Stanford, California \\ (C) 2003 by the Board of Trustees of the \\ Leland Stanford Junior University}

\section{Library of Congress Cataloging-in-Publication Data}

Lewin, Linda.

Surprise heirs, vol. 1 : illegitimacy, patrimonial rights, and legal nationalism in Luso-Brazilian inheritance, 1750-1821 / Linda Lewin.

p. $\mathrm{cm}$.

Includes bibliographical references and index.

ISBN 0-8047-3881-5 (cloth : alk. paper) -

1. Illegitimacy-Brazil-History-19th century. 2. BrazilSocial conditions-19th century. I. Title.

KHD520.L49 2003

346.8105 '2-dc21

2002010019

This book is printed on acid-free, archival-quality paper.

Original printing 2003

Last figure below indicates year of this printing:

$\begin{array}{llllllllll}12 & 11 & 10 & 09 & 08 & 07 & 06 & 05 & 04 & 03\end{array}$

Designed and typeset at Stanford University Press in 10/13 Minion 
For a new generation of historians of Brazil, who write the history of the family from the archives and frame their inquiry within a transatlantic perspective 
